\title{
(2) Case of acute kidney injury due to bilimbi fruit ingestion \\ OPEN ACCESS
}

\author{
Koh-Wei Wong, ${ }^{1}$ Meryl Grace Lansing ${ }^{2}$
}

'Department of Medicine, Hospital Queen Elizabeth, Kota Kinabalu, Sabah, Malaysia ${ }^{2}$ Medical Based Department, Universiti Malaysia Sabah, Kota Kinabalu, Sabah, Malaysia

Correspondence to Dr Meryl Grace Lansing; meryl.lansing@ums.edu.my

Accepted 6 July 2021

\section{Check for updates}

(C) BMJ Publishing Group Limited 2021. Re-use permitted under CC BY-NC. No commercial re-use. See rights and permissions. Published by BMJ.

To cite: Wong K-W, Lansing MG. BMJ Case Rep 2021;14:e242325. doi:10.1136/bcr-2021242325

\section{SUMMARY}

Bilimbi fruit is widely eaten in Malaysia. Rarely reported is its potential to cause acute kidney injury (AKI) in patients with prior normal renal function. The possible dangers of its consumption are still relatively unknown among many. This case highlights the importance of taking a thorough dietary history in patients with AKI. We also hope to increase awareness among healthcare professionals on the nephrotoxic and neurotoxic effects of bilimbi fruits.

\section{BACKGROUND}

Bilimbi fruit (Averrhoa bilimbi), otherwise known as 'belimbing buluh' in Malay and 'tulod ulod' in Dusun, is a popular tropical fruit. The fruit is sour and has a characteristic cylindrical shape. Bilimbi fruit can be eaten raw, cooked or pickled. Bilimbi fruit is often considered a medicinal fruit and used to treat various ailments such as cough and rheumatism. However, the fruit contains high oxalic acid levels and may become nephrotoxic when consumed in large quantity,. ${ }^{1}$ Over the years, there have been case reports from tropical countries documenting its neurotoxicity and nephrotoxicity among patients with chronic kidney disease (CKD). ${ }^{2}$ Rarely reported, it may also cause acute kidney injury (AKI) in people with normal renal function. Here we present a case of AKI after the ingestion of bilimbi fruit.

\section{CASE REPORT}

A 34-year-old man who is a smoker, with no significant medical or surgical history, presented with a 5 -day history of abdominal pain and diarrhoea. $\mathrm{He}$ has no family history of renal diseases. The colicky abdominal pain started at the left iliac fossa radiating to the back and the whole of the abdomen. One day before the onset of the abdominal pain, he consumed about $1 \mathrm{~kg}$ of bilimbi fruits (about 40 fruits). He was afebrile on presentation, and his blood pressure was $158 \mathrm{~mm} \mathrm{Hg}$ (systolic) and $101 \mathrm{~mm} \mathrm{Hg}$ (diastolic). Abdominal examination revealed mild tenderness over the lower umbilical region, and he had no pedal oedema. Cardiovascular and respiratory examinations were normal. His urine output remained good.

\section{INVESTIGATIONS}

Biochemical investigations revealed a serum creatinine of $633.89 \mu \mathrm{mol} / \mathrm{L}$, potassium of $3.9 \mathrm{mmol} / \mathrm{L}$ and urea of $10.1 \mathrm{mmol} / \mathrm{L}$. His urinalysis was normal, with no proteinuria or microscopic haematuria. Ultrasonography of his abdomen showed no evidence of obstructive uropathy. He was started on amlodipine $5 \mathrm{mg}$ daily for his hypertension. Further investigations were antistreptolysin- $\mathrm{O}$ titre which was negative; both $\mathrm{C} 3$ and $\mathrm{C} 4$ were raised; antinuclear antibodies were negative; hepatitis B surface antigen and hepatitis antibody (anti-hepatitis C virus) were non-reactive. Since admission, his serial serum creatinine levels were in a decreasing pattern $-633 \mu \mathrm{mol} / \mathrm{L}$ (day 1), $442 \mu \mathrm{mol} / \mathrm{L}$ (day 2), $401.8 \mu \mathrm{mol} / \mathrm{L}$ (day 3 ), $368.5 \mu \mathrm{mol} / \mathrm{L}$ (day 4), $331.3 \mu \mathrm{mol} / \mathrm{L}$ (day 5), $315.2 \mu \mathrm{mol} / \mathrm{L}$ (day 6 ). $\mathrm{He}$ was discharged on day 6 in view of his improving kidney function.

\section{OUTCOME AND FOLLOW-UP}

On outpatient review, his renal function slowly improved. Three weeks later, he reported dizziness with the amlodipine, and he stopped taking it. His blood pressure without the medication on review was $134 \mathrm{~mm} \mathrm{Hg}$ (systolic) and $94 \mathrm{~mm} \mathrm{Hg}$ (diastolic). His creatinine continued to improve to $169 \mu \mathrm{mol} / \mathrm{L}$ (day 11), $99.05 \mu \mathrm{mol} / \mathrm{L}$ (at 6 weeks), $107.63 \mu \mathrm{mol} / \mathrm{L}$ (at 10 weeks), $76.76 \mu \mathrm{mol} / \mathrm{L}$ (at 8 months).

\section{DISCUSSION}

Although bilimbi fruit is widely consumed in Malaysia, AKI due to Averrhoa bilimbi is rare, and case reports documenting its toxicity are scarce. Its nephrotoxicity is due to oxalate crystal deposition resulting in acute oxalate nephropathy, affecting people with normal kidney function, but more frequently in those with renal dysfunction. ${ }^{2}$ Bakul et al from India reported a series of cases in Kerala where 10 patients developed AKI following ingestion of bilimbi fruit juice where 7 out of 10 required haemodialysis. ${ }^{3}$ Nair et al also reported two cases of acute renal injury after both patients took bilimbi fruit juice as a presumed treatment for dyslipidaemia. ${ }^{4}$ The renal biopsy findings from patients who developed AKI following bilimbi fruit ingestion showed acute tubulointerstitial nephritis and tubular obstruction with calcium oxalate deposits. It is believed that the nephrotoxicity comes from the direct tubular damage from the calcium oxalate crystal obstruction of the tubules. Other mechanisms such as oxidative stress causing direct renal cytotoxic effects and apoptosis, indirect renal cytotoxic effects and necroinflammation from the crystals, and impairment of intracellular calcium homeostasis may also account for the severity and extent of renal damage. ${ }^{5}$ Consideration of other factors predisposing to AKI, such as the role of genetic and epigenetic and the effects of pre-existing comorbidities, may aid in further understanding of 
the mechanisms involved in AKI secondary to dietary oxalate. Although the exact amount of bilimbi fruit ingestion (either the fruit or the fruit juice) that may cause toxicity is not determined, ingestion of a large number of fruits or its juice or ingestion on an empty stomach seems to be the risk factor. Magnesium and calcium ions in food bind to oxalate in the gastrointestinal tract, thus preventing oxalate absorption. Ingestion of bilimbi fruit on an empty stomach may result in increased oxalate absorption, leading to AKI. Some patients (such as ours here) may not require dialysis, but others may need haemodialysis or haemoperfusion. Peritoneal dialysis was reported to be ineffective in the presence of neurological manifestations.

Averrhoa bilimbi and Averrhoa carambola (starfruit) belong to the family Oxalidaceae and share similar biochemical properties. ${ }^{6}$ There are many reported cases of star fruit-induced oxalate nephrotoxicity in those with existing renal impairment. However, the oxalic acid content in star fruit is less than bilimbi $(0.8-7.3 \mathrm{mg} / \mathrm{g}) .^{1}$ Simon et al reported a case of an elderly woman with CKD on dialysis who presented with intractable hiccups and altered sensorium following ingestion of both bilimbi and star fruit. The convincing time relationship between the ingestion of these fruits and the onset of symptoms in this case strongly suggests caramboxin intoxication. ${ }^{2}$ In 2017, Caetano et al described the case of a patient with CKD on dialysis who developed neurological symptoms after the ingestion of bilimbi fruit, similar to those related to star fruit ingestion. ${ }^{6}$ Initially, it was thought the neurotoxicity was due to the high oxalate content of the fruit, but recent findings seem to suggest another neurotoxin, called caramboxin, as the responsible agent. Caramboxin is an amino acid analogue and is metabolised and excreted by the kidneys. Caramboxin has an excitatory, seizure-causing and neurodegenerative action. The neurotoxic effects of caramboxin may be mediated by increased excitation (due to activation of NMDA, AMPA and kainate receptors) or decreased inhibition (due to decreased GABA binding). In patients with normal renal function, the neurotoxin is absorbed, distributed and excreted by the kidneys. In patients with CKD, the neurotoxin cannot be eliminated effectively by the kidneys, and its toxic effect may be fatal. The neurological symptoms of hiccups, vomiting, mental confusion, agitation and seizures in a patient with end-stage renal disease may be confused by other differential diagnoses such as uraemic encephalopathy and meningoencephalitis. The symptoms are known to occur within hours of ingestion; thus, a history of ingestion of the fruit may be the most crucial clue to the diagnosis in an acute setting. Caramboxin is water soluble and dialysable, and therefore intense dialysis may improve the outcome.

Despite their popularity, the potential harms of the tropical fruit bilimbi, and its close relative, the starfruit, are not well known. AKI may occur in patients with prior normal renal function following ingestion of bilimbi fruit, especially when taken in large quantity. Therefore, efforts must be made to ensure that healthcare professionals are aware of its potential neurotoxicity and nephrotoxicity. This case highlights the importance of a thorough dietary history in patients with AKI. Patients with CKD, especially those in the advanced stage, should be advised against eating bilimbi fruits.

\section{Learning points}

- A thorough dietary history should be included in all patients with acute kidney injury.

- Healthcare professionals should be aware of the potential neurotoxic and nephrotoxic effects of bilimbi fruits.

- Patients with chronic kidney disease, especially those in the advanced stage, should be advised against eating bilimbi fruits.

Acknowledgements The authors would like to thank the Director General of Health Malaysia for the permission to publish this paper.

Contributors $\mathrm{K}-\mathrm{WW}$ - data collection and writing the main content of the case report. MGL-editing and writing the summary, background and parts of the discussion.

Funding The authors have not declared a specific grant for this research from any funding agency in the public, commercial or not-for-profit sectors.

Competing interests None declared.

Patient consent for publication Obtained.

Provenance and peer review Not commissioned; externally peer reviewed.

Open access This is an open access article distributed in accordance with the Creative Commons Attribution Non Commercial (CC BY-NC 4.0) license, which permits others to distribute, remix, adapt, build upon this work non-commercially, and license their derivative works on different terms, provided the original work is properly cited and the use is non-commercial. See: http://creativecommons.org/ licenses/by-nc/4.0/.

\section{REFERENCES}

1 LIMA VLAGDE, MÉLO EDEA, SANTOS LIMA LDOS. Physicochemical characteristics of BILIMBI (Averrhoa bilimbi L.). Rev Bras Frutic 2001;23:421-3.

2 Simon S, Thomas J, Jayaram V. Status epilepticus owing to consumption of seasonal fruit in dialysis: case report. J Clin Nephrol Ren Care;6:055.

3 Bakul G, Unni VN, Seethaleksmy NV, et al. Acute oxalate nephropathy due to 'Averrhoa bilimbi' fruit juice ingestion. Indian J Nephrol 2013;23:297-300.

4 Nair S, George J, Kumar S, et al. Acute oxalate nephropathy following ingestion of Averrhoa bilimbi juice. Case Rep Nephrol 2014;2014:240936.

5 Yasawardene P, Jayarajah U, De Zoysa I, et al. Mechanisms of StAR fruit (Averrhoa carambola) toxicity: a mini-review. Toxicon 2020;187:198-202.

6 Caetano CP, de Sá CB, Faleiros BAP, et al. Neurotoxicity following the Ingestion of Bilimbi Fruit (Averrhoa bilimbi) in an End-Stage Renal Disease Patient on Hemodialysis. Case Rep Nephrol Dial 2017;7:6-12.

Copyright 2021 BMJ Publishing Group. All rights reserved. For permission to reuse any of this content visit

https://www.bmj.com/company/products-services/rights-and-licensing/permissions/

BMJ Case Report Fellows may re-use this article for personal use and teaching without any further permission.

Become a Fellow of BMJ Case Reports today and you can:

- Submit as many cases as you like

- Enjoy fast sympathetic peer review and rapid publication of accepted articles

- Access all the published articles

- Re-use any of the published material for personal use and teaching without further permission

Customer Service

If you have any further queries about your subscription, please contact our customer services team on +44 (0) 2071111105 or via email at support@bmj.com.

Visit casereports.bmj.com for more articles like this and to become a Fellow 